\title{
Ontologies of Play: Reconstructing the Relationship between Audience and Act in Early English Drama \\ CLARE WRIGHT \\ University of Kent
}

In his contribution to Shakespeare's Globe: A Theatrical Experiment, Mark Rylance describes how the reconstructed Globe has affected modern performance practice. Shakespeare's plays, he suggests, only really come to life in the Globe when "there is a sense of dialogue with the audience," when actors "speak and move with [them] in the present" (106-7). As a director, therefore, it

became paramount to say to the actors, "Don't speak to [the audience], don't speak for them, speak with them, play with them" [. . .] it was not just about speaking, it was about thinking of the audience as other actors, and not only when you were projecting onto them the role of the helpful crowd [...] it was more about the fact that anything they did was like another player on the stage doing something (Rylance 106-7).

These comments are obviously valuable as evidence of a distinctive "Globe performativity" (Worthen 84), but they also, and perhaps more significantly, call into question a central critical paradigm: specifically, the ontological relationship between audience and play. This relationship is often figured in terms of the distinction between a "play world" and the "real world," implying that dramatic characters and events occupy a time and space (a reality) ontologically separate from that of the audience. Rylance's comments about the actoraudience relationship at Shakespeare's Globe, however, seem to contradict this paradigm, which underpins much of our thinking about early English dramatic form, technique, and effect. In this article, I want to explore further the potential disjunction between modern and early concepts of dramatic ontology and to test current paradigms against the evidence from 
early English playtexts and records. In doing so, I will suggest that the continued use of the play-world-real-world paradigm in early drama studies is indicative of an enduring, if unconscious, conceptual bias towards post-nineteenth-century spatial and dramaturgical aesthetics and illustrate the incompatibility of this model with the extant evidence of early dramatic practice. Because early modern playwrights and players were building on an earlier performance tradition, I will, however, venture back into the dramatic heritage of early modern playhouses to explore late-medieval drama and its contexts. If the later commercial theaters were adapting earlier dramaturgical strategies, then it is also likely that they and their audiences similarly assumed earlier ideas about the relationship between audience and play. For the purposes of this discussion, I will focus on vernacular biblical plays, in part because of their frequent use as starting points for critics drawing connections between medieval and early modern dramatic praxis, but also because this is where the current paradigm most obviously breaks down, calling into question its use in other early dramatic modes.

\section{Modern Theatrical Paradigms}

In her landmark book Space in Performance, Gay McAuley proposes that the "space the spectator is watching during performance ... is always both stage and somewhere else" to the extent that the stage fictionalizes "whatever is presented on it" (27-28). McAuley is here describing the supposed ontology of play in a "conventional" theater space; that is, a purposebuilt, indoor theater with a clearly-defined stage, the majority of which projects back from the audience, perhaps behind a proscenium arch. Even though the "spectators are aware of their own reality" in such a space, McAuley writes, "they dismiss or relegate to a lower level of awareness of this knowledge in order to enter fully into the emotions of the fiction" (253). The architecture of many modern theaters, then, frames the action taking place on the stage as distinctly separate from that in the auditorium, its location and time, a conceptual relationship 
that seems to spill out into other modern spatial configurations, so that even when audiences are positioned spatially proximate to performers, for example, there is still a perceived separateness, an "audience/actor (us/them) relationship" (Machon 26). ${ }^{1}$

In recent years, this relationship has been questioned, challenged, and politicized by both critics and practitioners. ${ }^{2}$ My concern here, however, is not to engage with these debates, but to highlight the model's influence on critics of medieval and early modern drama. Martin Stevens, for example, in a provocative essay from 1971, deals explicitly with the perceived tensions between illusion and reality, aiming to show how the "artistic achievement of the medieval drama has been obscured or ignored because it has been judged by standards that applied to the ... naturalist stage" (449). For Stevens, pioneers like E. K. Chambers and Karl Young were clearly "influenced by the Social Darwinists," but were also molded by expectations derived from "the naturalistic theatre of illusion" (449). Here, Stevens makes a welcome claim against the assumed naivety of pre-Shakespearean drama, but in doing so he too adopts naturalist theatrical assumptions. For example, despite his earlier emphasis on medieval drama's categorization as game and clear statements about the audience as participants rather than spectators, he argues that medieval audiences of the Towneley Crucifixion could still, through Christ's direct address, be "drawn fully into the theatrical illusion," although the play's employment of "anti-illusionist devices" ensured that they were "never fully allowed to confuse theatrical action for reality" (Stevens 454-55). Nearly thirty years later, Jerzy Limon also characterized "the peculiar features of theatre" in terms of a clear division "between two times and two spaces, that of the performers and that of the spectators" (46). This division lies, he suggests, "at the very roots of the rise of theatre and drama," and their "evolution and the whole history of theatre may in fact be depicted as a constantly changing relationship between two spaces and between two times" (Limon 46). Indeed, theater's “essential feature is the creation of a fictional reality .... Without that 
fictional reality no theatre is possible" (Limon 48). Andrew Gurr has likewise described Shakespearean drama as a tradition playing with the distinctions between illusion, fiction, and reality. "The Shakespeareans were against illusionism," he writes (Shakespearean Stage 7); "lacking any proscenium arch to separate players from audience the presentation of illusion as reality for Shakespeareans" was, therefore, "inevitably more complicated than in modern theatres" (Shakespearean Stage 221). In Playgoing in Shakespeare's London, he proposes that "Speaking in verse rather than prose, delivering your mind in soliloquy as a person in solitude yet speaking directly to the immediately accessible listeners at your feet, using boys to play women, allowing clowns to ad-lib with their hecklers" are devices with "deliberate inhibitions against the easier kinds of illusionism" and work to "deny illusionism" (124-5).

In expressing such views, Stevens, Limon, and Gurr are reiterating long-held beliefs about the essential nature of theater; but what about the nature of drama performed before theater, and the structure and practices that word denotes, existed in England, before the notion of theatrical illusion itself was established? Dramatic devices can surely only actively "deny illusionism" if "the presentation of illusion as reality" was part of the established dramatic aesthetic (as with Brecht's epic theater and the "dramatic" theater that preceded it). But, as this essay will go onto to argue, it is not at all clear that in early drama it was a part of the established aesthetic, at least, not in the ways we might expect. Moreover, the dramaturgical features highlighted by Gurr as denying illusionism (speaking in verse rather than prose, direct address, boys playing women) are conventions inherited from earlier dramatic forms that aimed neither to present fiction or to create an illusion of reality. ${ }^{3}$

Even more radical approaches, like Robert Weimann's theory of locus and platea, rely on the play world/real world binary. Influenced by Marxist criticism and Brecht's epic theatre, Weimann looks back to what he understands as the "popular tradition" of the later Middle Ages. As outlined in the introduction to this special issue, it is in the 
"representational" space of the locus where he suggests "illusion and interpretation first begin to assert themselves" because "[a]ssociated with the scaffold[,] [the locus] is a rudimentary element of verisimilitude" (Popular Tradition 75). The platea, in contrast, "provided an entirely nonrepresentational and unlocalized setting; it was the broad and general acting area in which the communal festivities were conducted" (Popular Tradition 79). Underlying the fluid relationship between locus and platea, he goes on to write,

are the assumptions of a theater that establishes a flexible relationship between the play world and the real world ... What is involved, though, is not the confrontation of the world and time of the play with that of the audience ... but the most intense interplay of both (Popular Tradition 80).

It is, furthermore, through this intense interplay that "the audience's world is made part of the play and the play is brought into the world of the audience" (Popular Tradition 83).

In his later Author's Pen and Actor's Voice, Weimann further hardens the functional difference between locus and platea. Here the platea is more specifically an "opening in the mise-en-scène through which the place and time of the stage-as-stage and the cultural occasion itself are made either to assist or resist the socially and verbally elevated, spatially and temporally remote representation" (181). The locus is, therefore, positioned more explicitly as an "imaginary locale or self-contained space in the world of the play" (Author's Pen 181). Participating "in a symbolic abstraction from the here and now," it represented "a fairly verisimilar topos removed from direct audience rapport" and worked to "insulate" or "safeguard" the "representations from the circumstantial world of theatrical production and reception" (Author's Pen 183-88). To summarize, rather than having two distinct worlds, juxtaposed but completely separated from one another (as in naturalism), Weimann 
hypothesizes two distinct spaces (the play world, represented by the locus, and the real world, inhabited by the audience) connected by the fluid platea, a non-time, non-space.

The idea of a flexible dramaturgy has had radical implications for our understanding of early English performance and its effects, and most scholars now acknowledge the inherent connection between the play and its audience's "reality." ${ }^{4}$ However, Weimann's elaboration of locus and platea in his later book underscores the model's rootedness in postnaturalist ontologies and representational practices, despite (or perhaps because of) the influence of Brecht on his thinking. The proliferation of "illusion" and "verisimilitude" and phrases like "play world," "real world," and especially "mise-en-scène," in Weimann's analysis clearly indicate the aesthetic point of origin for his explanations of medieval and early modern dramatic devices. ${ }^{5}$ As Lawrence Clopper has so convincingly shown, however, such terms were not a part of medieval dramatic vocabulary, suggesting that these concepts do not reflect actual practice. Both "illusion" and "theater" existed in Latin and vernacular forms throughout the Middle Ages, and they were used by medieval writers, but never in relation to contemporary performance. As Clopper argues, for most medieval writers, plays were not associated "with the theatrum either in mode or content ... because mode and content were pious" (3). In contrast, "the theatrum was a place for spectacle, it was also a place of obscenities" (3). For St Augustine and Isidore of Seville, who influenced latermedieval ideas about theater, the "craft of acting [was an] overtly false mode of signification" and so the "performers' actions and gestures by definition represented fictions," embodying either the actions of false gods or the actions of men within a material world (Dox 56-61). As such, "theater" was a term used for tournament grounds and other secular game places. It is in this semantic context that we find Chaucer using the word in "The Knight's Tale", describing Theseus's arena for the tournament that will decide which of the two Theban knights will marry Emily (Chaucer line 1885). Similarly, “illusion” holds very specific meaning for 
medieval writers, readers and audiences. It implies either derision and mockery or deceit and falsehood, the former often used in commentary on the mocking and buffeting of Christ, the latter in relation to the magical tricking of the senses, delusions of the mind, devilish deceits, and false faith. These meanings are obviously not what modern critics intend when using such terms and there is equally little evidence to suggest that our modern ideas of theater reflect medieval perspectives on drama. Many late-medieval Latin stage directions do illustrate contemporary use of locus and platea, and many in English likewise make mention of spaces that mark, for example, a house belonging to a particular character, hell, or heaven, as well as references to "the place." mark are by no means ubiquitous, and there is no evidence to suggest that verisimilar or illusionistic representations, rudimentary or otherwise, are indicated by their use, or are even of concern to late-medieval playwrights and players. Indeed, such terms and concepts are entirely unsuited to discussions of biblical and moral dramas, which, as I will go on to illustrate, aimed not to deceive or trick their audiences, but to illuminate a spiritual truth obscured by the material illusions of earthly and bodily existence.

As Clopper suggests, then, it is likely that in applying modern theatrical terms to medieval texts and documents, we have "theatricalized'-made into theater-activities that do not properly belong in that category as we understand it" (4). We have put "the theater at the center of the discussion" and in the process have forced "the documents to operate within that arena" (4). ${ }^{7}$ Furthermore, in theatricalizing early drama, in assuming that the main aim was to create a verisimilar illusion of reality, we have also assumed that the audience must be ontologically separate from the play world, imposing a modern ontology of play onto dramas performed in a time when theater, as we perceive it, did not yet exist. If drama in this earlier, "pre-theatrical" period did not necessarily aim to create a "fictional reality" or illusion, how does that affect our understanding of it and the commercial playhouses that inherited its 
dramaturgical strategies? How might it impact the theories and methodologies of "reconstruction" or the ways in which we might approach practice-based research more broadly?

\section{Reconstructing Late-Medieval Ontologies of Play}

To think about these questions further, I want now to turn to late-medieval drama, its contexts, and how they might have influenced the perceived ontology of performance. The first thing to recognize, of course, is the nature of the material presented. Rather than enacting fictional narratives or mythological stories, the English biblical dramas presented what were perceived to be historical and spiritual truths. For example, the famous York Corpus Christi Play presented key episodes in human history: that which was past (Creation, the Fall, the Nativity, the Crucifixion), but also that which was to come (Doomsday). Even non-biblical plays presented such truths. For instance, the Digby Mary Magdalene and The Conversion of St. Paul recount apparently true events in the lives of saints, their miracles, and pieties; allegorical plays like Mankind, Wisdom, or the famous Everyman articulate abstract moral truths, and the spiritual dilemmas and paths that all humanity must negotiate on the pilgrimage back to God.

The primary purpose of these plays was not simply to entertain; they could, of course, do so, but that amusement often also contributed to their devotional aims and agendas, and therefore their affective impact. We might think here of the charismatic Vices of Mankind who lure their audiences through humor, tricking them into participating in a blasphemous song and the eventual corruption of Mankind, an allegorical representation of themselves. The great northern cycle plays, like those of York and Chester, and many other biblical dramas, were in the main concerned with worship and so designed to augment, bolster, and reform a community's faith. The plays were, therefore, devotional acts in 
themselves and not merely didactic presentations that taught a supposedly illiterate laity basic Christian tenets, as the early-fifteenth-century Dives and Pauper argues:

Steraclis, pleyys \& dauncis pat arn don principaly for deuocioun \& honest merthe [to teche men to loue God pe more] \& for no rybaudye, ne medelyd with no rybaudye [ne lesyngis], arn leful (Commandment III, Cap. xvii, 13-16).

Note the explicit point that "leful" (lawful) spectacles (steraclis), plays, and dances should contain neither "rybaudye" nor "lesyngis" (lies), but should be didactic and must "teche men." However, here at least, they are not perceived primarily as tools to teach lewd folk the basic principles of their faith; rather, plays should teach all men to "loue God pe more," that is, more deeply, for the purpose of "deuocioun" and an "honest merthe."8

Producing these plays was, then, a pious undertaking, which perhaps further suggests that performing in them was also not simply an act of mimicry or imitation; it was likewise an act of devotion, as a number of playtexts indicate. ${ }^{9}$ In the early-sixteenth-century, East-Anglian play The Killing of the Children, for example, Poeta's introduction firmly locates the event as part of local celebrations marking the Feast of St Anne, the mother of the Virgin Mary. Poeta then goes on to outline the purpose and nature of the performance:

These grett thynges remembred after our entent, Is for to worshippe oure ladye and seynt Anne.

We be comen heder as seruauntes diligent, Our processe to shew you as we can (17-20). 
This is perhaps one of the most explicit dramatic statements in pre-playhouse drama. The players have come to the performance place "as seruauntes diligent," their "entent" (intention) to "worshippe" both the Virgin Mary and St Anne by remembering these "grett thynges" (the conception, birth and sacrifice of Christ) through the re-enactment of Herod's Slaughter of the Innocents. The word "processe" in the last sentence is important as the term identifying how the act of performance was perceived in this particular context. In Middle English it not only means a sequence or succession of events, but can also refer to a narrative discourse, a story or historical account, a book of the Bible, as well as an exegetical discourse, all of which work within the context of a devotional act. In the context of the play, then, it not only marks the performance that follows as a story sequence, but as a reenactment, a remembrance, an explication of those events, and an act of worship. Its use in Poeta's introduction is perhaps, therefore, an echo of terms used in liturgical drama. ${ }^{10} \mathrm{~A}$ part of religious service, such performances were called "tropes," "offices," "lessons," "services," in which members of the clergy represented, imitated, signified, and depicted episodes from a shared Christian past. ${ }^{11}$ Through the clerical community's representation of an event like the three Marys' Visit to the Sepulcher, what was re-created and remembered was revived, and the past event was given immediacy in the present moment, a concept encapsulated in Rogier van der Weyden's “Seven Sacraments" triptych (fig. 1). In effect, the disparate times and spaces of the then and the now were collapsed, folded together, united and merged through performance. [Insert Fig. 1]

The coincidence of biblical past with contemporary present is also a feature of latemedieval lay devotion, probably the most important context for late-medieval performance ontology. The practice of imitatio christi, for example, as Jesse Njus has recently argued, allowed "practitioners and spectators alike ... to participate in sacred history [and] to blend it with the medieval present" (2). Affective piety, perhaps the most widespread lay devotional 
form, likewise sought to close the distance, both temporal and conceptual, between biblical history and the present moment. Affective piety encouraged the devotee to focus on the humanity of Christ, his birth, life, and death as a way to understand and come closer to a God who might otherwise seem unknowable. To do so, it was suggested that the individual should imagine Christ's human relationships and experiences by making reference to his or her own earthly interactions, literally fleshing out the Gospel accounts with human understandings of family, friendship, love, pain, and loss. Devotional manuals offered vernacular guidance on meditation for the laity, of which Nicholas Love's translation and adaptation of the PseudoBonaventuran Meditationes Vitae Christi was the most popular. ${ }^{12}$ Throughout the book, the reader is instructed to behold and imagine, but in the description of the Crucifixion Love changes tack, suggesting that the reader "make pe pere present in pi mynde, beholding all pat shal be done azeynus pi Lorde Jesu" (43.7-8). At this crucial moment, the devotee is not only to imagine the events of the Crucifixion, but to make him- or herself present at those events, to imagine occupying a space in the crowd on Mount Calvary, watching passively as the soldiers crucify Christ. This is, of course, also one purpose of the donor portraits included in many contemporary stained glass images, manuscript illuminations, sculpted or painted depictions of biblical or spiritual scenes. The donors who have paid for that piece of devotional art are, in effect, inserting themselves into the historical events or into the presence of the divinity or saint depicted. Both acts, as in liturgical performance, collapse time and space, bringing historical past and contemporary present together, thereby reinforcing the immediacy, relevance and significance of biblical events for the individual, as well as his/her own role in those past episodes.

These, then, are key contexts for understanding late-medieval biblical drama. Presenting historical and spiritual truths that had a bearing on the lives of all humanity, these plays were performative acts of devotion. Connected with the objectives and ideas of both 
formal worship and personal piety, they were not necessarily solemn, but made use of the peculiar characteristics of drama to illustrate the proximity and importance of those vital events to persons living in the here-and-now. In these plays, therefore, as in the art, devotion and ritual of the period, "[t]he 'then' of history becomes the "now" of the individual, as contemporary man is given a "rôle in a constantly on-going process ... of our continuing salvation and damnation" (Mills 4). The York Pinners' Crucifixion pageant is perhaps the most famous example of such spatio-temporal unity in the corpus of medieval drama. Performed annually in the streets of York from the middle of the fourteenth century until 1569 (two years after the first mention of the Red Lion and only seven years before the building of the Theatre), the pageants were often (though not always) performed using wagons, which were pulled along a designated route through the City, stopping at officially authorized "stations" along the way so the players could perform their given episode. The precise mechanics of this process are still uncertain, but clearly the players would be very close to the audience, who either stood in the street around the wagon or, if they were wealthy enough, watched from the upper stories of houses along the pageant route or from specially-erected scaffolds. ${ }^{13}$ As participants in a community endeavor it was possible that players were known to many in the audience, the symbols of the trade or craft guild to which they belonged as much a part of their wagon dressings as the biblical episodes they were to present. The city itself would also have been permanently present to those watching and performing in the Corpus Christi Play; phenomenologically present to their visual, aural and olfactory senses and also present through the ideological, cultural and practical associations of the sites designed and otherwise used for other purposes, both daily and occasional (an issue of central importance to Eleanor Rycroft's article in this special issue). The city and its inhabitants, both those watching and those performing, would not, therefore, disappear from either visual or conceptual awareness; instead, their presence and identities would inevitably 
become integrated into the play's plot, rooting its re-enactment of historical events in the immediate here-and-now.

The playwright's awareness of these features is much in evidence in the Pinners' playtext, and he clearly uses them to aid the devotional aims of the pageant. For instance, Christ, elevated on the cross, addresses "Al men pat walkis by waye or strete," commanding them to:

Byholdes myn heede, myn handis, and my feete, And fully feele nowe, or ze fyne, Yf any mournyng may be meete, Or myscheue mesured vnto myne (253-8).

This is clearly a direct address to those gathered before the player in the street below, indicated by the reference to "waye" and "strete," the command to "beholdes" and "feele," and the use of the second person plural pronoun, "ze." Christ here figures the audience as the historically raucous crowd gathered at, or passing by, the foot of the cross, as depicted in Jan van Eyk's diptych featuring the Crucifixion (fig. 2). If the cross were elevated on a wagon, those in the street would occupy a similar perspective to the figures at the foot of the cross in van Eyk's painting, and so, as with Love's Mirror and the donor portraits in devotional imagery, by watching York's Crucifixio Christi the audience can become part of the crowd in a simulation (or re-enactment) of that event. But, of course, it is not just the audience who were refigured; the city would also have been changed through performance, becoming simultaneously both York and Jerusalem. The York Play worked with the city as a lived space, each station having its own particular timbre and significance for the community. In performance, those meanings would merge with those generated by the pageant. As in 
modern site-specific productions, then, the site permeated performance, and performance probably lingered within the site. ${ }^{14}$ This would, moreover, have been an important part of the play's function in the community, as evidence from comparable modern productions, like the Beverley Passion Play, illustrate. [Insert Fig. 2]

The Beverley Passion Play is not based on medieval playtexts or traditions, even though the town historically hosted biblical dramas. Nevertheless, its agendas and its staging practices, as Diana Wyatt recently suggested, offer interesting parallels to the medieval tradition that might help us think through actor-audience and spatial dynamics in preplayhouse drama. Established in 2009, the play arose from the town's annual Good Friday procession, in which the cross was carried by members of various churches, through the streets of Beverley towards the Saturday Market, where a short service would be held. Like late-medieval sources, the information on the play's website implicitly assumes the truth of what is being re-enacted. The aim of the current play is "to present the events of the last week of Jesus' life" and so "key moments" have been selected to "give an impression of the events as they unfolded" (The Beverley Passion 2016). The similarities between biblical Jerusalem and twenty-first-century Beverley are also highlighted and, although there is no express attempt to unify the two spaces, the producers do hope that those watching "get a real sense of what it would have been like to witness these events first-hand" ("Beverly Passion"). These underlying aims make the Beverley Passion Play very different from the many York Mystery Play productions that seek "to create a bold, exhilarating piece of story-telling theatre on an operatic scale" ("York Mystery Plays 2012") or a "breath-taking production of the city's most famous stories" ("Minster Mystery Plays"), and allow "local people to become engaged with their history to create performances which have met with popular, critical and academic acclaim" ("York Mystery Plays: Brought Forth ..."). Obviously, the devotional, theological, and cultural contexts of the Beverley Passion Play are not those of 
fifteenth-century York, and neither are the dramatic practices. Nonetheless, the above are important parallels that make this production closer in many respects to late-medieval biblical plays than the modern "reconstructions" and productions of cycle plays at York and Chester. They highlight, for instance, the importance of devotion and belief in the production and experience of the play, emphasizing the very different relationship between act and audience created by such a perspective.

Looking at a still from the 2009 Beverley Passion Play, then, we can see how site inflects the play, how the play works with the site, and how both fuse to generate an experience that works to reinforce the perceived truthfulness and continued relevance of this event. ${ }^{15}$ As in medieval plays, the cross functions as the locus, marking the site of Christ's crucifixion. But, what is apparent in this modern performance is that the locus does not appear to be, in Weimann's terms, "insulated" or "removed" from the town surrounding it. Note the very present lamp-post, the concrete, the stone and brick houses, TV aerials, the steward in the high-visibility jacket, the orange cable or rope snaking across the playing space, and the audience who sit at its edges. If we do not assume that the actors occupy a separate play world and instead recognize both the devotional and experiential contexts of performance, then it seems obvious to say that actors and audience here are occupying the same spatio-temporal reality, even though the actors wear "historical" costumes and the cross is obviously not an everyday object within the town square. Imagine now that, as with the York Play, the audience know the players, who wear modern, rather than historic, clothing, as the performers of the 2014 York Crucifixion and The Death of Christ did (fig. 3), and as the crowd at the foot of the cross in van Eyck's painting do. Like the fifteenth-century painting, then, it is a modern European city that is the site of Christ's trials, and it is the modern citizens of the town who watch, with varying degrees of attention, his crucifixion. The spatial parallels between this still from the Beverley Play and the van Eyck painting are also striking. 
Their proximity to the cross and behaviors clearly implicate van Eyck's crowd in the event, the contemporary location, costumes, and embedded donor portraits reaching beyond the confines of the image to also implicate the viewer. The audience at Beverley are obviously behaving very differently, politely conforming to the modern rules of play; yet, they are still implicated in the action. By conforming to the rules of play, in which they must not interfere with the performance, and yet occupying the same spatio-temporal location as the action, they stand in for those historic figures who also stood passively, watching an innocent man be crucified. The extended meaning of this is, as it would probably have been at York, that the audience too, in their everyday lives in this modern town, are both the cause and beneficiaries of Christ's sacrifice, the merging of historic and contemporary locales making that point explicit by figuring the modern individual in that historic event, and providing them with a very real, visceral experience of it. [Insert Fig. 3]

\section{Ontologies of Play: Some Suggestions}

Within such a performance environment, does it make sense to speak of the locus as, in Weimann's terms, a "spatially and temporally remote representation," an "imaginary locale or self-contained space in the world of the play"? In medieval biblical plays, working within the contexts of affective piety and a theology that emphasized the coincidence of the "then" and the "now," was the locus in any sense trying to create an illusion of a fictional reality, "a symbolic abstraction from the here and now," distinct from the 'real world' and yet connected to it via a permeable platea, that mysterious "opening in the mise-en-scene"? To assume so, I suggest, contradicts the contextual, textual, record, and practice-based evidence, disregarding what they reveal about medieval ontologies of play. Trying to split the pageant wagon as locus from the audience's reality, from the contemporary site, and the activity occurring all around it, actively works against the aims and objectives of medieval drama. 
The whole point of events like the York Play was to affect participants, to bring them closer to the biblical past, its spiritual relevance, and the divine truths revealed through it. By reenacting key events in the here-and-now the pageants, like other devotional modes, sought to collapse time and space, to merge biblical past with the medieval present, so that participants might not only understand the events of the past, but also their own direct contributions to it and, therefore, their role in the outcomes of sacred history. As with the spatial relations in modern site-specific and immersive theatre (explored by Dustagheer, below), then, the audience was not ontologically separated from the world of the action, "but in it, of it, surrounded by it, dwelling in it, travelling through it; the space is thus integrated within and as the world in which the audience-participants are immersed which ensures this sense of 'rootedness' in the world of the event is actively felt" (Machon 127). ${ }^{16}$

The ontology of play might initially seem a rather pedantic, marginal point in the history of English drama, but, as this article has indicated, how it is perceived and understood affects many other elements of dramatic production and reception. It underpins, for example, the relationship and interaction between players and audiences, and so also determines what role the audiences have (whether they are spectators, participants or collaborators, for example), what devices are used as a result of that relationship, and what their effect might be on both audience and act. It also affects fundamental aspects of performance, like representational practices, performance style, the demarcation and occupation of space, and the action's relationship with the everyday beyond its boundaries. Questioning the current ontological paradigm of play could, therefore, have wide-reaching consequences for early drama studies, opening the door to new ways of thinking about the functioning and history of early drama in England. This article has focused on late-medieval and modern religious drama, and shown the inadequacies of using current ontological paradigms to analyze them. Elizabethan and Jacobean playhouses clearly had very different objectives and purposes, not 
to mention dramatic material; nevertheless, the evidence now arising from projects like Shakespeare's Globe points towards a similar disjunction in later drama studies, especially when data from REED and the revisionary AHRC-funded Before Shakespeare project show the playhouses operating alongside traditional, well-established playing practices still active across London. Surely, then, both players and audiences would bring the conceptual frameworks associated with those established practices with them to these new spaces. In which case, in addition to being "attentive to the organizing spatial principles of locus and platea," as Rycroft argues in this special issue (placeholder page ref.), reconstruction and practice-based research must also take into account pre-modern dramatic ontologies, the core conceptual paradigms that inspired such methods. Therefore, for practice-as-research to break new ground in understanding early modern drama and what was truly new about the playhouses, for it to find fresh ways of thinking about pre-modern drama, it must not only explore dramatic spaces, places and practices, but must also recognize the cultural contingency of the idea and the essential nature of performance itself.

\section{Notes}

${ }^{1}$ Many dramatic forms, like pantomime, and individual productions, work to break down actor-audience divisions, but generally, within these spaces, they have to work quite hard to do so successfully.

${ }^{2}$ See, for example, Rancière.

${ }^{3}$ For further criticism on "stage-centered" approaches, see Escolme.

${ }^{4}$ The model has not been without its critics, however: see Lin.

5 According to the $O E D$, the earliest usage of "verisimilitude" in English is in Philemon Holland's 1603 translation of Plutarch's Moralia ("verisimilitude"). The first recorded 
instance of "mise-en-scène" is in a diary entry of 1833, recounting a performance of Shakespeare's Coriolanus ("mise-en-scène").

${ }^{6}$ See, for example, The Castle of Perseverance, N-Town The Trial before Annas and Cayphas, and the Digby Mary Magdalen.

${ }^{7}$ For a similar discussion, see Symes.

${ }^{8}$ In contrast, the York Creed Play document states that it was dedicated "to the glory of God and especially to the instruction of the people." In particular, it is noted that the play should educate "the ignorant" about the Creed. See Johnston, "The Plays of the Religious Guilds of York."

${ }^{9}$ Margaret Rogerson has recently argued along similar lines.

${ }^{10}$ It is important to note that "liturgical drama" and "liturgy" are also not medieval terms.

${ }^{11}$ For examples, see the Visitatio Sepulchri from the Regularis Concordia, the Ad Faciendam Similitudinem Dominici Sepulcri and the Ordo ad Repraesentandum Herodem from Fleury, and the Ordo ad Peredrinum in Secunda Feria Pasche as Vesperas from Beauvais. All are available with modern English translations in Bevington, ed., Medieval Drama.

12 There are strong similarities between Love's description of the Passion (The Mirror ch. 43) and the York Play of the Crucifixion.

${ }^{13}$ For discussions of York Play staging practices see Marshall; McKinnell; Mills, "I Know My Place"; and Twycross, "The Left-hand-side Theory" and "Forget the 4.30 A.M. Start."

${ }^{14}$ For recent discussions see Badir; Haddad; and Teo.

${ }^{15}$ I was unable to obtain a high-resolution image before going to press. The image under discussion, entitled "end-richards addresses the audience," is available on the Beverley Passion Play gallery. 
${ }^{16}$ A different argument is put forward by Eleanor Rycroft in this special issue. She argues that, in plays like Fulgens and Lucres, two places exist simultaneously, as the represented space of the play is "layered" on top of the real location (placeholder page ref.).

\section{Works Cited}

Badir, Patricia. “'The whole past, the whole time': Untimely Matter and the Playing Spaces of York." Performing Environments: Site-Specificity in Medieval and Early Modern English Drama, edited by Susan Bennett and Mary Polito, Palgrave Macmillan, 2014, pp. 17-38.

Before Shakespeare: The Beginnings of London Commercial Theatre, 1565-1595. 2016, beforeshakespeare.com/. Accessed Jan. 30, 2017.

“The Beverley Passion”. 2016, beverleypassion.org/. Accessed Apr. 9, 2016.

The Beverly Passion. Directed by Sandra King, performances by Mark Merriweather and Richard Bradbury. Apr. 10, 2009, the Saturday Market, Beverley. Performance.

Bevington, David, editor. Medieval Drama. Houghton Mifflin, 1975.

The Castle of Perseverance. The Macro Plays. Edited by Mark Eccles, Early English Text Soc. vol. 262, Oxford UP, 1969, pp. 3-111.

Chaucer, Geoffrey. “The Knight's Tale." The Riverside Chaucer, edited by Larry D. Benson. $3^{\text {rd }}$ ed., Houghton, 1980, pp. 37-66.

Clopper, Lawrence M. Drama, Play and Game: English Festive Culture in the Medieval and Early Modern Period. U of Chicago P, 2001.

The Conversion of St Paul. The Digby Plays. Edited by F. J. Furnivall, Early English Text Soc., e.s 70, Oxford UP, 1967, pp. 27-52.

Crucifixio Christi. The York Plays. Edited by Richard Beadle, Early English Text Soc., s.s. 23, vol. 1, Oxford UP, 2009, pp. 332-41. 
The Crucifixion and Death of Christ. Directed by Tom Straszewski, performances by John Hayland, Paul Yates, Fiona Jackson, Chris Haygard, and Richard Thirlwall. Jul. 13, 2014, St Sampson Square, York. Performance.

Dives and Pauper. Edited by Priscilla Heath Barnum, vol. 1, Early English Text Soc. o.s. 275, Oxford UP, 1976.

Dox, Donnalee. The Idea of the Theater in Latin Christian Thought. U of Western Michigan P, 2004.

Dustagheer, Sarah. “'Intimacy' at the Sam Wanamaker Playhouse.” Shakespeare Bulletin, vol. 35, no. 2, 2017, pp. placeholder ref.

Dustagheer, Sarah, Oliver Jones, and Eleanor Rycroft. “(Re)constructed Spaces for Early Modern Drama: Research in Practice.” Shakespeare Bulletin, vol. 35, no. 2, pp. placeholder ref.

"end-richards addresses the audience." The Beverley Passion, beverleypassion.org/images/phocagallery/thumbs/phoca_thumb_1_end\%20\%20richards\%20addresses\%20the\%20audience.jpg. Accessed Mar. 17, 2017.

Escolme, Bridget. Talking to the Audience: Shakespeare, Performance, Self. Routledge, 2005.

Everyman. Medieval Drama: An Anthology edited by Greg Walker, Blackwell, 2000, pp. 290-97.

Gurr, Andrew. Playgoing in Shakespeare's London. $3^{\text {rd }}$ ed., Cambridge UP, 2004.

---. The Shakespearean Stage, 1574-1642. $4^{\text {th }}$ ed., Cambridge UP, 2009.

Haddad, Tamara. "Locating the Drama: Micklegate Bar and the Skinners' Entry into Jerusalem." The Mediaeval Journal vol. 4, no. 2, 2014, pp. 83-102. 
“illusioun, n.” Middle English Dictionary Online. The Regents of the University of Michigan, 2014, quod.lib.umich.edu/cgi $/ \mathrm{m} / \mathrm{mec} / \mathrm{med}-$

idx?size=First+100\&type=orths\&q1=illusioun\&rgxp=constrained. Accessed Apr. 9, 2016.

Johnston, Alexandra F. "The Plays of the Religious Guilds of York: The Creed Play and the Pater Noster Play.” Speculum, vol. 50, no. 1, 1975, pp. 55-90.

Johnston, Alexandra F., and Margaret Rogerson, editors. Records of Early English Drama: York. Manchester UP, 1979. 2 vols

The Killing of the Children. The Digby Plays. Edited by F. J. Furnivall, Early English Text Soc., e.s 70, Oxford UP, 1967, pp. 1-24.

Limon, Jerzy. "From Liturgy to the Globe: The Changing Concept of Space." Shakespeare Survey, vol. 52, 1999, pp. 46-53.

Lin, Erika T. "Performance Practice and Theatrical Privilege: Rethinking Weimann's Concepts of Locus and Platea." New Theatre Quarterly, vol. 22, no. 3, 2006, pp. 283-89.

Love, Nicholas. The Mirror of the Blessed Life of Jesus Christ. Edited by Michael G. Sargent, U of Exeter P, 2004.

Machon, Josephine. Immersive Theatres: Intimacy in Contemporary Performance. Palgrave Macmillan, 2013.

Mankind. The Macro Plays. Edited by Mark Eccles, Early English Text Soc. vol. 262, Oxford UP, 1969, pp. 154-84.

Marshall, John. "Nailing the Six-Wheeled Wagon: A Sideview." Medieval English Theatre, vol. 12 , no. 2, 1990, pp. 96-100.

Mary Magdalen. The Digby Plays. Edited by F. J. Furnivall, Early English Text Soc., e.s 70, Oxford UP, 1967, pp. 55-136.

McAuley, Gay. Space in Performance: Making Meaning in the Theatre. U of Michigan P, 1999. 
McKinnell, John. "The Medieval Pageant Wagons at York: Their Orientation and Height." Early Theatre, vol. 3, 2000, pp. 79-104.

Mills, David. "I Know My Place: Some Thoughts on Status and Stations in the English Mystery Plays.” Medieval English Theatre, vol. 27, 2005, pp. 5-15.

Mills, David. “The 'Now' of 'Then.'” Medieval English Theatre, vol. 22, pp. 2000, pp. 3-12. The Minster Mystery Plays. The Chapter of York, 2015, yorkminster.org/mysteryplays2016/home.html. Accessed Apr. 9, 2016.

“mise-en-scène, n.” OED Online, Oxford UP, 2016, oed.com/view/Entry/119505?redirectedFrom=mise-en-sc\%C3\%A8ne+\#eid. Accessed April. $11,2016$.

Njus, Jesse. "What Did It Mean to Act in the Middle Ages?: Elisabeth of Spalbeek and Imitatio Christi." Theatre Journal, vol. 63, no. 1, 2011, pp. 1-21.

Pearson, Mike. Site-Specific Performance. Palgrave Macmillan, 2010. “processe, n." Middle English Dictionary Online, The Regents of the University of Michigan, 2014, quod.lib.umich.edu/cgi/m/mec/medidx $?$ size $=$ First $+100 \&$ type $=$ orths \&q1 $1=$ processe $\&$ rgxp=constrained. Accessed Apr. 9, 2016. Rancière, Jacques. The Emancipated Spectator. Translated by Gregory Elliot, Verso, 2009. Rogerson, Margaret. "Affective Piety: A Method for Medieval Actors in the Chester Cycle." The Chester Cycle in Context, 1555-1575, edited by Jessica Dell, David Klausner, and Helen Ostovich, Ashgate, 2012, pp. 93-110.

Rycroft, Eleanor. "Place on the Late Medieval and Early Modern Stage: The Case of Ane Satyre of the Thrie Estaitis." Shakespeare Bulletin, vol. 35, no. 2, 2017. pp. placeholder ref. Rylance, Mark. "Research, Materials, Crafts: Principles of Performance at Shakespeare's Globe." Shakespeare's Globe: A Theatrical Experiment, edited by Christie Carson and Farah Karim-Cooper, Cambridge UP, 2008, pp. 103-114. 
Stevens, Martin. "Illusion and Reality in the Medieval Drama." College English, vol. 32, no. 4, 1971, pp. 448-64.

Symes, Carol. "The Medieval Archive and the History of Theatre: Assessing the Written and Unwritten Evidence for Premodern Performance.” Theatre Survey, vol. 52, no. 1, 2011, pp. $29-58$.

Teo, Kevin. "Mapping Guild Conflict in the York Passion Plays." Performing Environments: Site-Specificity in Medieval and Early Modern English Drama, edited by Susan Bennett and Mary Polito, Palgrave Macmillan, 2014, pp. 41-58.

The Trial before Annas and Cayphas. The N-Town Play. Edited by Stephen Spector, Early English Text Soc. s.s. 11, vol. 1, Oxford UP, 1991, pp. 295-304.

Twycross, Meg. "Forget the 4.30 A.M. Start: Recovering a Palimpsest in the York Ordo Paginarum.” Medieval English Theatre, vol. 25, 2003, pp. 98-152.

---. "The Left-hand-side Theory: A Retraction.” Medieval English Theatre, vol. 14, 1992, pp. 77-94.

"verisimilitude, n." OED Online, Oxford 2016, oed.com/view/Entry/222523?redirectedFrom=verisimilitude+\#eid. Accessed Apr. 11, 2016. Weimann, Robert. Author's Pen and Actor's Voice: Playing and Writing in Shakespeare's Theatre. Edited by Helen Higbee and William West, Cambridge UP, 2000.

---. Shakespeare and the Popular Tradition in the Theater: Studies in the Social Dimension of Dramatic Form and Function. Edited by Robert Schwartz, Johns Hopkins UP, 1978.

Wisdom. The Macro Plays. Edited by Mark Eccles, Early English Text Soc. vol. 262, Oxford UP, 1969, pp. 114-51.

Worthen, W. B. Shakespeare and the Force of Modern Performance. Cambridge UP, 2003. 
Wyatt, Diana. “'I'd have dressed for the occasion': Reflections on Audience Engagement with Biblical Plays." Medieval English Theatre Meeting, Mar. 29, 2014, Murray Edwards College, University of Cambridge. Conference Paper.

“The York Mystery Plays 2012. The Vision". York Mystery Plays, 2012, web.archive.org/web/20160315230554/http://www.yorkmysteryplays-2012.com/page/thevision.php. Accessed Apr. 9, 2016.

York Mystery Plays: Brought Forth by the York Guilds and Companies. York Festival Trust, 2016, yorkmysteryplays.co.uk/. Apr. 9, 2016. 